\title{
Andrew Konove, Black market capital: urban politics and the shadow economy in Mexico City, Oakland, California, University of California Press, 2018, 304 pp.
}

\author{
Javier Torres Medina ${ }^{1} *$ (D)
}

${ }^{1}$ Tecnológico de Monterrey Campus Estado de México, México.

*Correspondencia: jtm@itesm.mx
"Y iay, ay, ay! Que desgracia, Ya pasó el Baratillo, Ya pasó, valedores, A la plaza de Tepito..." -Romero (1990, p. 84) 1

Las investigaciones sobre la economía informal han tenido un repunte actualmente en México y aunque hay varios grupos de investigación, no se le ha dado la importancia debida como un fenómeno creciente que generalmente se visualiza en el ambulantaje, en la venta callejera y en negocios no registrados oficialmente y que, aunque es muy evidente, está, como estaba en el pasado, en las sombras de la ilegalidad, como así lo apunta Andrew Konove en este libro en el que utiliza dos conceptos interesantes que dan título a su obra: black market y shadow economy que son definiciones que se empatan con el concepto de economía informal. Ambas definiciones se refieren más a una práctica ilegal de productos u objetos robados o prohibidos y, aunque en el texto se aclara, es necesario apuntar que estos conceptos no definen todo el espectro de mercancías que se vendía en las calles y plazas de la ciudad de México que, a guisa de mercados, eran herederos de los tianguis

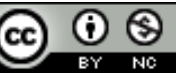

Esta obra está protegida bajo una Licencia Creative Commons Atribución-NoComercial 4.0 Internacional

\footnotetext{
${ }^{1}$ Tonadilla popular citada en Romero, H. (1990). El tianguis: un viaje a un mundo mágico de México. México: Cámara de Comercio de la ciudad de México.
} 
prehispánicos. La economía informal, subterránea, emergente o de subsistencia, se evidenciaba en esos espacios para el intercambio, en estos mercados en los que también se desarrollaban ciertas prácticas ilícitas. Durante el periodo colonial el contrabando y la compraventa de mercancías prohibidas estaban ocultos o en las sombras y se practicaban junto con la vendimia de alimentos, artesanías, antigüedades, baratijas y objetos de segunda mano.

El mercado El Baratillo es tomado por Konove como ejemplo y eje para construir su argumentación. A través de una historia de larga duración que va desde finales del siglo XvII hasta principios del siglo xx, el autor explica cómo los distintos gobiernos y administraciones trataron de controlar el espacio público ocupado por el mercado en la Plaza Mayor. La disputa por el espacio urbano fue una constante entre las autoridades que intentaban aplicar un ordenamiento y los vendedores que defendían su derecho a usar plazas y calles para ganarse la vida. En esos espacios públicos se tejían desordenes, motines, revueltas, rebeliones y protestas contra el orden establecido, es decir, no sólo era un espacio para la vendimia, sino que también lo era para las tensiones, los pleitos y las disputas que provocaban un tour de force entre los diferentes gobiernos y los baratilleros.

El Baratillo era un espacio esencial para la venta de mercancía de todo tipo y proveía de empleo a cientos de personas. Los espacios ocupados donde se practicaba el intercambio de productos de toda laya era una constante en la ciudad de México. Es por eso que el mercado beneficiaba a muchos agentes económicos no sólo por ser centro de abasto, sino de proveer ingresos para el ayuntamiento y de ciertas prácticas de corrupción harto frecuentes, como mordidas, gratificaciones, sobornos y trapacerías que conformaban ese espacio de la shadow economy. Asimismo, este mercado constituyó un espacio de integración y de interacción en donde no sólo pululaban las clases bajas, pobres, léperos, mal entretenidos, vagos y artesanos, sino que era visitado por criollos, comerciantes y empresarios que compartían ese espacio público utilizado para el intercambio, y podían estar juntos, pero no revueltos, como se dice en México.

Estudios como el que ofrece Konove son importantes porque explican desde la perspectiva histórica el fenómeno de la informalidad y de los mercados negros y revela una dimensión interesante para comprender un problema que no sólo no se ha detenido o inhibido, sino que se ha incrementado en economías emergentes. Las imágenes de la ciudad de México en litografías y grabados donde se observan calles y plazas llenas de puestos y cajones dispuestos para la vendimia desde el siglo xviII, resultan muy similares a los que observamos hoy. Entonces como ahora, se muestra la lucha de amplias capas de la población marginada como vendedores ambulantes por permanecer en la calle y en los espacios públicos a pesar de los intentos gubernamentales por reubicarlos, meterlos en mercados y ordenar el espacio público.

Esta historia de larga duración, que abarca el derrotero del mercado popular El Baratillo desde sus orígenes coloniales hasta fines del siglo XIX, es estudiada en seis capítulos. En el primero se analizan los esfuerzos de las autoridades para eliminar este mercado popular ubicado en la plaza principal de la ciudad de México y que no sólo proveían del abasto necesario a la población de Nueva España, sino que se practicaba el intercambio de cualquier tipo de mercancías ilícitas que le daban un carácter de mercado negro.

A partir de las revueltas y disturbios que se dieron desde la década de 1690, el mercado sufrió diferentes transformaciones y cambios incluso de lugar. El moverlo de sitio implicó su control y su reordenamiento, aspectos que se tocan en un segundo capítulo y fue en la época borbónica que se aplicaron políticas de ordenamiento urbano bajo criterios racionales. Konove no sólo estudia el mercado como espacio de transacciones comerciales o económicas, sino donde se daban relaciones culturales y constituía un escenario donde transcurría la vida cotidiana, con todos sus problemas; 
pleitos, motines, revueltas y actos criminales. El mercado prosperó en un espacio disputado entre las autoridades y los baratilleros; su existencia misma era una contradicción legal puesto que las autoridades reales $-\mathrm{y}$ luego las nacionales- lo prohibieron repetidamente, pero los funcionarios locales permitieron que continuara, tratándolo, de alguna manera, como cualquier otro mercado público.

En un tercer capítulo el autor analiza la shadow economy a través del debate entre las elites con ideas renovadoras y las prácticas del comercio cotidiano a fines del siglo XvIII y principios del XIX. En ese periodo se suscitaron conflictos y problemas en torno a la venta de productos y mercancías prohibidas junto con mercancías de uso común, por lo que los intentos por criminalizar esta práctica enfrentaron a las autoridades con los baratilleros. En este contexto, el Ayuntamiento de la ciudad de México tuvo un papel relevante en la permanencia de los comerciantes en esos espacios. Este aspecto se continúa en el capítulo cuarto en que se aborda el periodo llamado época de Santa Anna. En el quinto capítulo se explica cómo las ideas del libre comercio después del triunfo de la república influyeron en el derrotero del Baratillo y establecieron nuevas disposiciones y reglamentos basados en una nueva definición del concepto de lo público. En el sexto y último capítulo se exploran las políticas modernizadoras durante la administración de Porfirio Díaz y la continuación de las negociaciones y los conflictos durante el periodo revolucionario, en donde Konove observó cómo las redes informales, que mantuvieron el intercambio de bienes ilícitos y de segunda mano, convergían en el Baratillo, lo cual evitó en cierta medida los embates del furor revolucionario en la ciudad de México. Durante el periodo posrevolucionario, los baratilleros sostuvieron su comercio no a través de la resistencia violenta o la protesta pública, sino a través de un hábil uso de las instituciones mexicanas. La historia del Baratillo arrojó luz sobre un sistema político urbano que era rutinariamente capaz de producir compromisos, como lo apunta Konove.

Las autoridades fueron disputándose el control y la administración de la plaza, hasta que se le otorgó al Ayuntamiento su administración, tanto del espacio como de los puestos, que terminaros reubicados en lo que hoy conocemos como Tepito que en la actualidad muestra esas características del antiguo mercado que históricamente se fue desarrollado, con la venta de alimentos, objetos de segunda mano, mercancías robadas, piratas y proveniente de la fayuca.

El libro comienza y termina presentando un aspecto interesante para la ciudad de México: la existencia de Tepito, que intriga a los extranjeros -quizá de la misma manera que nos intriga a los chilangos-. El Barrio Bravo, cuya definición no alcanza a caracterizar todo lo que representa, queda de manera implícita en el libro, sobre todo hacia el presente, lo cual no es una carencia del texto, sino una brecha propositiva y sugerente. Tepito, en efecto, es el mercado más famoso, pero no el único.

Actualmente los mercados informales proliferan en prácticamente todas las ciudades del país; los tianguis y la venta callejera se ha desbordado y es evidente en toda la ciudad, aunque no se le observa, ni se le ve, ni se le estudia detenidamente, salvo cuando se utiliza como criadero de clientela política. Por ejemplo, el tianguis de la san Felipe (colonia San Felipe de Jesús, alcaldía de Gustavo A. Madero) se prolonga y se ha desbordado hasta el Estado de México y son tantos los vendedores que no se sabe con certeza cuánta gente vende, compra o asalta ahí. No hay ni siquiera algo parecido a un censo ni una regulación, pero se piensa que es el mercado informal más grande de América Latina. Es necesario ahondar más en la problemática del incremento de la economía informal y su impacto y relación con la economía formal, de ahí la importancia de estudios como el presente. 
El comercio informal en la zona de Tepito ha crecido de modo dramático en las últimas décadas originando serios problemas en los espacios urbanos en donde se concentra, ocupando calles, plazas públicas y casi en su totalidad los espacios peatonales y diversificando la comercialización de diversas mercancías incluyendo el tráfico de drogas. Ese espacio "negro" todavía tiene mucho que desvelar. 